\title{
Multiplex real-time PCR assay for detection of Escherichia coli 0157:H7 and screening for non-0157 Shiga toxin-producing E. coli
}

Baoguang $\mathrm{Li}^{1 *} \mathbb{D}$, Huanli Liu ${ }^{2}$ and Weimin Wang ${ }^{1}$

\begin{abstract}
Background: Shiga toxin-producing Escherichia coli (STEC), including E. coli O157:H7, are responsible for numerous foodborne outbreaks annually worldwide. E. coli O157:H7, as well as pathogenic non-O157:H7 STECs, can cause lifethreating complications, such as bloody diarrhea (hemolytic colitis) and hemolytic-uremic syndrome (HUS). Previously, we developed a real-time PCR assay to detect E. coli O157:H7 in foods by targeting a unique putative fimbriae protein Z3276. To extend the detection spectrum of the assay, we report a multiplex real-time PCR assay to specifically detect E. coli O157:H7 and screen for non-O157 STEC by targeting Z3276 and Shiga toxin genes (stx1 and stx2). Also, an internal amplification control (IAC) was incorporated into the assay to monitor the amplification efficiency.

Methods: The multiplex real-time PCR assay was developed using the Life Technology ABI 7500 System platform and the standard chemistry. The optimal amplification mixture of the assay contains $12.5 \mu$ l of $2 \times$ Universal Master Mix (Life Technology), $200 \mathrm{nM}$ forward and reverse primers, appropriate concentrations of four probes [(Z3276 (80 $n M)$, stx1 $(80 \mathrm{nM})$, stx2 (20 nM), and IAC (40 nM)], $2 \mu$ l of template DNA, and water (to make up to $25 \mu$ in total volume). The amplification conditions of the assay were set as follows: activation of TaqMan at $95^{\circ} \mathrm{C}$ for $10 \mathrm{~min}$, then 40 cycles of denaturation at $95^{\circ} \mathrm{C}$ for $10 \mathrm{~s}$ and annealing/extension at $60{ }^{\circ} \mathrm{C}$ for $60 \mathrm{~s}$.

Results: The multiplex assay was optimized for amplification conditions. The limit of detection (LOD) for the multiplex assay was determined to be $200 \mathrm{fg}$ of bacterial DNA, which is equivalent to 40 CFU per reaction which is similar to the LOD generated in single targeted PCRs. Inclusivity and exclusivity determinants were performed with 196 bacterial strains. All E. coli O157:H7 $(n=135)$ were detected as positive and all STEC strains $(n=33)$ were positive for stx1, or stx2, or stx 1 and stx2 (Table 1). No cross reactivity was detected with Salmonella enterica, Shigella strains, or any other pathogenic strains tested.
\end{abstract}

Conclusions: A multiplex real-time PCR assay that can rapidly and simultaneously detect E. coli O157:H7 and screen for non-O157 STEC strains has been developed and assessed for efficacy. The inclusivity and exclusivity tests demonstrated high sensitivity and specificity of the multiplex real-time PCR assay. In addition, this multiplex assay was shown to be effective for the detection of $E$. coli O157:H7 from two common food matrices, beef and spinach, and may be applied for detection of E. coli O157:H7 and screening for non-O157 STEC strains from other food matrices as well.

Keywords: Multiplex real-time PCR, Escherichia coli O157:H7, Shiga toxins (stx1, stx2), Shiga toxin-producing E. col (STEC), non-O157, Limit of detection (LOD), Pathogen detection, Sensitivity

\footnotetext{
* Correspondence: baoguang.li@fda.hhs.gov

'Division of Molecular Biology, Center for Food Safety and Applied Nutrition,

Food and Drug Administration, Laurel, MD 20708, USA

Full list of author information is available at the end of the article
}

\section{Ciomed Central}

(c) The Author(s). 2017 Open Access This article is distributed under the terms of the Creative Commons Attribution 4.0 International License (http://creativecommons.org/licenses/by/4.0/), which permits unrestricted use, distribution, and reproduction in any medium, provided you give appropriate credit to the original author(s) and the source, provide a link to the Creative Commons license, and indicate if changes were made. The Creative Commons Public Domain Dedication waiver (http://creativecommons.org/publicdomain/zero/1.0/) applies to the data made available in this article, unless otherwise stated. 
Table 1 Results of E. coli 0157:H7 and non-O157 STEC strains detected by the multiplex real-time PCR assay

\begin{tabular}{|c|c|c|c|c|c|}
\hline \multirow[t]{2}{*}{ Strain } & \multirow[t]{2}{*}{ Serotype } & \multirow[t]{2}{*}{ Source } & \multicolumn{3}{|c|}{ Target gene } \\
\hline & & & $Z 3276$ & $s t \times 1$ & st $\times 2$ \\
\hline EC1275 & O157:H7 & CDC EDL933, hamburger meat & + & + & + \\
\hline EC1225 & O157:H7 & WA, 1993 & + & + & + \\
\hline EC1759 & O157:H7 & USA (MI), 2003 & + & + & + \\
\hline EC1429 & O157:H7 & Denmark, 1987 & + & - & + \\
\hline EC4420 & O157:H7 & NY, 12/2006 & + & - & + \\
\hline EC4421 & O157:H7 & White Onions, NY, 12/2006 & + & + & + \\
\hline EC4422 & O157:H7 & White Onions, NY, 12/2006 & + & + & + \\
\hline EC4504 & O157:H7 & MN, 12/2006 & + & + & + \\
\hline EC1428 & O157:H7 & Argentina, 1977 & + & - & + \\
\hline EC1738 & O157:H7 & Food isolate & + & - & + \\
\hline EC1530 & O157:H7 & Thailand, 1994 & + & - & + \\
\hline EC4440 & O157:H7 & $C D C$ & + & + & + \\
\hline EC4163 & O157:H7 & USA (IL) & + & - & + \\
\hline EC4438 & O157:H7 & $C D C$ & + & - & + \\
\hline EC4431 & O157:H7 & NY, 12/2006 & + & - & + \\
\hline EC4452 & O157:H7 & USA (NJ), 2006 & + & - & + \\
\hline EC1709 & O157:H7 & USA (MI), 2002 & + & - & + \\
\hline EC1760 & O157:H7 & USA (MI), 2004 & + & - & + \\
\hline EC1431 & O157:H7 & Japan, 1987 & + & - & + \\
\hline EC4115 & O157:H7 & Sep-06 & + & - & + \\
\hline EC1734 & O157:H7 & MA, 2009 & + & - & + \\
\hline EC4302 & O157:H7 & NY, 12/2006 & + & + & + \\
\hline EC4301 & O157:H7 & NY, 12/2006 & + & + & + \\
\hline EC4429 & O157:H7 & NY, 12/2006 & + & - & + \\
\hline EC4428 & O157:H7 & NY, 12/2006 & + & - & + \\
\hline EC4437 & O157:H7 & NJ, 12/2006 & + & - & + \\
\hline EC4436 & O157:H7 & NJ, 12/2006 & + & - & + \\
\hline EC4434 & O157:H7 & NY, 12/2006 & + & - & + \\
\hline EC4433 & O157:H7 & NY, 12/2006 & + & - & + \\
\hline EC4432 & O157:H7 & NY, 12/2006 & + & - & + \\
\hline EC4449 & O157:H7 & NJ, 12/2006 & + & - & + \\
\hline EC4448 & O157:H7 & WI, 12/2006 & + & - & + \\
\hline EC4447 & O157:H7 & $C A, 12 / 2006$ & + & + & + \\
\hline EC4201 & O157:H7 & USA (CA), 2006 & + & - & + \\
\hline EC4456 & O157:H7 & USA (NJ),2006 & + & - & + \\
\hline EC4461 & O157:H7 & USA (NJ),2006 & + & - & + \\
\hline EC4502 & O157:H7 & USA (NJ),2006 & + & + & + \\
\hline EC4503 & O157:H7 & USA (NJ),2006 & + & + & + \\
\hline EC4505 & O157:H7 & USA (NJ),2006 & + & + & + \\
\hline EC4511 & O157:H7 & USA (NJ),2006 & + & + & + \\
\hline EC4200 & O157:H7 & USA (CA), 2006 & + & - & + \\
\hline EC1267 & O157:H7 & USA, (NH), 1991 & + & + & + \\
\hline EC1268 & O157:H7 & USA (MT), 1991 & + & + & + \\
\hline
\end{tabular}


Table 1 Results of E. coli O157:H7 and non-O157 STEC strains detected by the multiplex real-time PCR assay (Continued)

\begin{tabular}{|c|c|c|c|c|c|}
\hline \multirow[t]{2}{*}{ Strain } & \multirow[t]{2}{*}{ Serotype } & \multirow[t]{2}{*}{ Source } & \multicolumn{3}{|c|}{ Target gene } \\
\hline & & & $Z 3276$ & $s t \times 1$ & $s t \times 2$ \\
\hline EC4194 & O157:H7 & USA (CA), 2006 & + & - & + \\
\hline EC1590 & O157:H7 & USA (WA) & + & + & + \\
\hline EC4458 & O157:H7 & USA (NJ),2006 & + & - & + \\
\hline EC4197 & O157:H7 & USA (CA), 2006 & + & - & + \\
\hline EC1231 & O157:H7 & USA (WA), 1995 & + & + & + \\
\hline EC4470 & $\mathrm{O} 157: \mathrm{H7}$ & USA (NJ),2006 & + & - & + \\
\hline EC4471 & O157:H7 & USA (NJ),2006 & + & - & + \\
\hline EC1244 & O157:H7 & USA (GA), 1992 & + & + & + \\
\hline EC4199 & O157:H7 & USA (CA), 2006 & + & - & + \\
\hline EC1260 & O157:H7 & USA (GA),1993 & + & - & + \\
\hline EC4167 & O157:H7 & USA (WI), 2006 & + & - & + \\
\hline EC4168 & O157:H7 & USA (WI), 2006 & + & - & + \\
\hline EC4193 & O157:H7 & USA (OH), 2006 & + & - & + \\
\hline EC1265 & O157:H7 & USA (CA), 1993 & + & + & + \\
\hline EC4184 & O157:H7 & USA (IL), 2006 & + & - & + \\
\hline EC4204 & O157:H7 & USA (CA), 2006 & + & - & + \\
\hline EC4171 & O157:H7 & USA (WI), 2006 & + & - & + \\
\hline EC4205 & O157:H7 & USA (CA), 2006 & + & - & + \\
\hline EC4206 & O157:H7 & USA (CA), 2006 & + & - & + \\
\hline EC1593 & $\mathrm{O} 157: \mathrm{H7}$ & USA (MI), 2003 & + & + & + \\
\hline EC1239 & O157:H7 & USA (NE), 1993 & + & - & + \\
\hline EC4174 & $\mathrm{O} 157: \mathrm{H7}$ & USA (IL), 2006 & + & - & + \\
\hline EC4187 & O157:H7 & USA (CT), 2006 & + & - & + \\
\hline EC4188 & O157:H7 & USA (CT), 2006 & + & - & + \\
\hline EC4191 & $\mathrm{O} 157: \mathrm{H7}$ & Spinach, USA (IL), 2006 & + & - & + \\
\hline EC1276 & O157:H7 & Japan, 1996 & + & + & + \\
\hline EC4501 & O157:H7 & MN, 12/2006 & + & + & + \\
\hline EC558 & O157:H7 & Patient raw milk & + & + & + \\
\hline EC867 & O157:H7 & USDA-FSIS-380-94 & + & + & + \\
\hline EC874 & O157:H7 & Apple cider & + & + & + \\
\hline EC4162 & O157:H7 & Feces (New Jersey) & + & - & + \\
\hline EC506 & O157:H7 & Feces & + & - & + \\
\hline EC507 & O157:H7 & Feces & + & + & + \\
\hline EC4443 & O157:H7 & CDC & + & + & + \\
\hline EC4442 & O157:H7 & CDC & + & + & + \\
\hline EC4441 & O157:H7 & CDC & + & + & + \\
\hline EC4451 & O157:H7 & NJ, 12/2006 & + & - & + \\
\hline EC4445 & O157:H7 & NJ, 12/2006 & + & + & + \\
\hline EC4446 & $\mathrm{O} 157: \mathrm{H7}$ & NJ, 12/2006 & + & + & + \\
\hline EC1601 & O157:H7 & USA (MI), 2002 & + & + & + \\
\hline EC1727 & O157:H7 & Ml, 2002 & + & + & + \\
\hline EC1426 & O157:H7 & Canada, 1988 & + & - & + \\
\hline EC4419 & O157:H7 & NY, 12/2006 & + & - & + \\
\hline
\end{tabular}


Table 1 Results of E. coli O157:H7 and non-O157 STEC strains detected by the multiplex real-time PCR assay (Continued)

\begin{tabular}{|c|c|c|c|c|c|}
\hline \multirow[t]{2}{*}{ Strain } & \multirow[t]{2}{*}{ Serotype } & \multirow[t]{2}{*}{ Source } & \multicolumn{3}{|c|}{ Target gene } \\
\hline & & & $Z 3276$ & $s t \times 1$ & st $\times 2$ \\
\hline EC4418 & O157:H7 & NY, 12/2006 & + & - & + \\
\hline EC4417 & O157:H7 & NY, 12/2006 & + & - & + \\
\hline EC4416 & O157:H7 & NY, 12/2006 & + & - & + \\
\hline EC4423 & O157:H7 & NY, 12/2006 & + & - & + \\
\hline EC4424 & O157:H7 & NY, 12/2006 & + & - & + \\
\hline EC4427 & O157:H7 & NY, 12/2006 & + & - & + \\
\hline EC4426 & O157:H7 & NY, 12/2006 & + & - & + \\
\hline EC4435 & O157:H7 & NY, 12/2006 & + & - & + \\
\hline EC4425 & O157:H7 & NY, 12/2006 & + & - & + \\
\hline EC4164 & O157:H7 & USA (WI), 2006 & + & - & + \\
\hline EC4439 & O157:H7 & MS, 12/2006 & + & - & + \\
\hline EC4450 & O157:H7 & NJ, 12/2006 & + & - & + \\
\hline EC1217 & O157:H7 & 2003 & + & + & + \\
\hline EC1577 & O157:H7 & USA (WA), 1995 & + & + & + \\
\hline EC4201 & O157:H7 & USA (CA), 2006 & + & - & + \\
\hline EC4207 & O157:H7 & USA (IL), 2006 & + & - & + \\
\hline EC4208 & O157:H7 & Spinach, USA (IL), 2006 & + & - & + \\
\hline EC1245 & O157:H7 & USA (GA), 1995 & + & + & + \\
\hline EC4506 & O157:H7 & USA (MN), 2006 & + & + & + \\
\hline EC4507 & O157:H7 & USA (MN), 2006 & + & + & + \\
\hline EC4508 & O157:H7 & USA (MN), 2006 & + & + & + \\
\hline EC4509 & O157:H7 & USA (MN), 2006 & + & + & + \\
\hline EC4510 & O157:H7 & USA (MN), 2006 & + & + & + \\
\hline EC1590 & O157:H7 & USA (WA) & + & + & + \\
\hline EC1597 & O157:H7 & USA (CT), 1996 & + & + & + \\
\hline EC1225 & O157:H7 & USA (WA), 1993 & + & + & + \\
\hline EC1236 & O157:H7 & Food, USA (CA), 1993 & + & + & + \\
\hline EC1240 & O157:H7 & USA (OH), 1993 & + & + & + \\
\hline EC1241 & O157:H7 & Food, USA (OR), 1995 & + & + & + \\
\hline EC4472 & O157:H7 & USA, (NJ), 2006 & + & - & + \\
\hline EC1242 & O157:H7 & USA (GA), 1992 & + & - & + \\
\hline EC1243 & O157:H7 & USA (GA), 1992 & + & + & + \\
\hline EC4463 & O157:H7 & USA (NJ), 2006 & + & - & + \\
\hline EC4165 & O157:H7 & USA (WI), 2006 & + & - & + \\
\hline EC4166 & O157:H7 & USA (WI), 2006 & + & - & + \\
\hline EC4195 & O157:H7 & Spinach, USA (OH), 2006 & + & - & + \\
\hline EC4192 & O157:H7 & USA (CA), 2006 & + & - & + \\
\hline EC4182 & O157:H7 & USA (IL), 2006 & + & - & + \\
\hline EC4469 & O157:H7 & USA (NJ), 2006 & + & - & + \\
\hline EC4465 & O157:H7 & USA (NJ), 2006 & + & - & + \\
\hline EC4170 & O157:H7 & USA (WI), 2006 & + & - & + \\
\hline EC4183 & O157:H7 & USA (IL), 2006 & + & - & + \\
\hline EC4186 & O157:H7 & USA (IL), 2006 & + & - & + \\
\hline
\end{tabular}


Table 1 Results of E. coli O157:H7 and non-O157 STEC strains detected by the multiplex real-time PCR assay (Continued)

\begin{tabular}{|c|c|c|c|c|c|}
\hline \multirow[t]{2}{*}{ Strain } & \multirow[t]{2}{*}{ Serotype } & \multirow[t]{2}{*}{ Source } & \multicolumn{3}{|c|}{ Target gene } \\
\hline & & & $Z 3276$ & $s t \times 1$ & $s t \times 2$ \\
\hline Ec4169 & O157:H7 & USA (WI), 2006 & + & - & + \\
\hline EC4189 & O157:H7 & USA (CT), 2006 & + & - & + \\
\hline EC4175 & O157:H7 & USA (IL), 2006 & + & - & + \\
\hline EC4176 & O157:H7 & USA (IL), 2006 & + & - & + \\
\hline EC4444 & O157:H7 & USA, NJ, 2006 & + & + & + \\
\hline EC4173 & O157:H7 & USA (IL), 2006 & + & - & + \\
\hline EC1892 & O104:H4 & STEC, Republic of Georgia, 2011 & - & - & + \\
\hline EC1893 & O104:H4 & STEC, Republic of Georgia, 2011 & - & - & + \\
\hline EC1891 & O104:H4 & STEC, Germany, 2011 & - & - & + \\
\hline EC1894 & O104:H4 & STEC, Germany, 2011 & - & - & + \\
\hline EC1769 & $\mathrm{O} 26$ & STEC & - & + & - \\
\hline EC1770 & $\mathrm{O} 26$ & STEC & - & + & + \\
\hline EC1771 & $\mathrm{O} 26$ & STEC & - & + & - \\
\hline EC1773 & $\mathrm{O} 26: \mathrm{H} 11$ & STEC & - & + & - \\
\hline EC1775 & O26:H11 & STEC & - & + & - \\
\hline EC1768 & $\mathrm{O} 26: \mathrm{H} 2$ & STEC & - & + & - \\
\hline EC1786 & O111:NM & STEC & - & + & + \\
\hline EC1787 & O111:H8 & STEC & - & + & + \\
\hline EC1788 & O111:NM & STEC & - & + & - \\
\hline EC1791 & $\mathrm{O} 145: \mathrm{H} 25$ & STEC & - & - & + \\
\hline EC1794 & O145:NM & STEC & - & + & + \\
\hline EC1801 & O103:H2 & STEC & - & + & - \\
\hline EC1802 & O103:H25 & STEC & - & + & - \\
\hline EC1803 & O103:H11 & STEC & - & + & + \\
\hline EC1806 & O121:H19 & STEC & - & - & + \\
\hline EC1807 & O121:H19 & STEC & - & - & + \\
\hline EC1808 & O121:H19 & STEC & - & + & + \\
\hline EC331 & $\mathrm{O} 26$ & STEC & - & + & + \\
\hline EC400 & O26:H11 & STEC & - & + & + \\
\hline EC521 & O26:H11 & STEC & - & + & + \\
\hline EC540 & $\mathrm{O} 26: \mathrm{H}-$ & STEC & - & + & + \\
\hline EC550 & $\mathrm{O} 26: \mathrm{H}-$ & STEC & - & + & + \\
\hline EC1232 & $\mathrm{O} 55: \mathrm{H7}$ & STEC & - & + & + \\
\hline EC1235 & $\mathrm{O} 55: \mathrm{H7}$ & STEC & - & + & + \\
\hline EC1668 & O111:H8 & STEC & - & + & - \\
\hline EC1669 & O118:H16 & STEC & - & - & + \\
\hline EC1631 & O111:H8 & STEC & - & + & - \\
\hline EC1655 & O111:H8 & STEC & - & + & - \\
\hline K12 & & Negative E. coli strain control & - & - & - \\
\hline NTC & & & - & - & - \\
\hline
\end{tabular}

\section{Background}

Shiga toxin-producing Escherichia coli (STEC), including E. coli $\mathrm{O} 157: \mathrm{H7}$, is a heterogeneous group of enteric pathogens responsible for numerous sporadic infections and large outbreaks annually worldwide [1]. Besides $E$. coli O157:H7, non-O157 STEC strains are important 
foodborne pathogens estimated to cause over 112,752 cases illnesses each year in the United States [2]. Shiga toxin (Stx) production, especially Stx2, has been implicated as an important factor in causing severe disease and hemolytic uremic syndrome (HUS) [3-5].

E. coli serotype O157:H7 was first recognized as a causative agent of food contamination outbreaks in 1982 in Oregon and Michigan [6]. Since then, numerous $E$. coli $\mathrm{O} 157: \mathrm{H} 7$ outbreaks have been reported worldwide [7]. In the United States alone during 2003 - 2012, 390 outbreaks of $E$. coli $\mathrm{O} 157: \mathrm{H} 7$ infections were documented, which resulted in 4,928 illnesses, 1,272 hospitalizations, and 33 deaths [8]. The typical symptoms caused by E. coli O157:H7 include abdominal pain, watery diarrhea and potential progression to bloody diarrhea (hemorrhagic colitis) [9]. The pathological features of hemorrhagic colitis are attributed to the production of Shiga like cytotoxins (Stx1 and Stx2), which consists of a $32-\mathrm{kDa}$ A subunit and five identical 7.7 $\mathrm{kDa} B$ subunits. These toxins can bind to receptors located on membranes of eukaryotic cell and cause tissue damage resulting in pathological outcomes $[4,5,10,11]$. Non-O157 STEC strains are foodborne pathogens and have been responsible for sporadic cases of infections and outbreaks. Although O157:H7 has garnered more attention, primarily based on historical record, recent attention has recognized the significance of non-O157 STEC strains as a pathogen $[9,12-20]$. Considerable attention is now drawn to non-O157 STEC strains particularly after the occurrence of a severe foodborne outbreak happened in 2011 in Germany caused by consumption of sprouts contaminated by STEC O104:H4 [21].

The clinical significance and economic burden associated with outbreaks caused by E. coli $\mathrm{O} 157: \mathrm{H} 7$ and nonO157 STEC have led to development of a variety of detection methods. These include the application of conventional bacteriological methods using selective media or chromogenic agar, which usually take several days to complete $[1,9,22]$, and molecular-based assays such as PCR-based methods [23-25], microarray [25-27], and whole genomic sequencing (WGS) [25, 28, 29]. Of these molecular methods, real-time PCR is a commonly used method [9]. More importantly, real-time PCR enables detection to be coincided with the amplification process by the introduction of fluorogenic probes [23], and multiplex real-time PCR allows multiple genes to be simultaneously amplified either from one template [9] or multiple templates by using different primer pairs [24].

Multiplex real-time PCR has gained more acceptance and use due to its ability to its differentiation potential and reliability $[11,30]$. Various target genes have been used in PCR detection scheme for E.coli O157:H7, including the Shiga toxin genes (stx1 and stx2) $[9,12,13]$, eae [31, 32], fimA [33], rfbE [34], uidA [24, 35], and
Z3276 [23, 36, 37]. Of the target genes, uidA is most commonly used. Specificity with this gene is based on a highly conserved point mutation at position 93 of the $\beta$ glucuronidase gene $[38,39]$. However, when a uidAbased commercial kit was used for identification of a large number of $E$. coli $\mathrm{O} 157: \mathrm{H} 7$ isolates $(\mathrm{n}=391)$, numerus strains $(\mathrm{n}=21)$ did not generate an amplified product. This prompted us to search for a more specific and reliable gene target for detection of E. coli $\mathrm{O} 157: \mathrm{H} 7$ [23]. As a result, a real-time PCR-based on Z3276 gene, a putative unique fimbriae gene in E. coli $\mathrm{O} 157: \mathrm{H} 7$ [40], was developed. All the 391 isolates, including the 21 strains that were "negative" by the uidA-based commercial kit, that were tested were positively identified [23]. The primary focus of our previous study was to search for a unique genetic marker and the development of a real-time PCR assay for the detection of E.coli O157:H7, and the Shiga toxin genes were not included in that assay [23]. Since the annual number of episodes of domestically acquired foodborne illnesses caused by nonO157 STEC $(112,752)$ is almost doubled that of E. coli O157:H7 $(63,153)$ in the United States [2], the inclusion of the stx genes can be used as the primary characteristic for STEC detection within the heterogeneous STEC group [41]. Thus, in the present study, we incorporated in a multiplex real-time PCR assay the Z3276, st x1, and stx2 genes, as well as an internal amplification control to for detection of Escherichia coli O157:H7 and screening for non-O157 STEC. In addition, the assay was assessed with two common food matrices, beef and spinach, for specific detection of E. coli $\mathrm{O} 157: \mathrm{H} 7$ and non-O157 STEC strains.

\section{Methods}

\section{Bacterial strains and growth conditions}

All the E. coli $\mathrm{O} 157: \mathrm{H} 7$ and non-O157 STEC strains used in this study are listed in Table 1. EDL933 (ATCC 43985) was used as the E. coli $\mathrm{O} 157: \mathrm{H} 7$ reference strain. Strains of E. coli O157:H7 (n = 135) and non-O157 STEC ( $\mathrm{n}=33$ ) were used for inclusivity determination. Salmonella enterica strains, Shigella strains and other pathogenic strains were used for the exclusivity test (Table 2). These strains are all from the strain collections of Division of Molecular Biology, Food and Drug Administration (FDA).

\section{Bacterial DNA preparation}

Bacteria were grown at $37^{\circ} \mathrm{C}$ in Luria-Bertani (LB) broth with agitation at $180 \mathrm{rpm}$, or on LB agar placed in a gravity convection incubator. Bacterial growth was measured by monitoring the turbidity at $600 \mathrm{~nm}\left(\mathrm{OD}_{600}\right)$ using a DU530 spectrophotometer (Beckman, CA). To enumerate bacterial cells, cultures were diluted serially in 10-fold increments with medium and plated on LB 
Table 2 Detection results of the exclusivity test with different bacterial strains by the multiplex real-time PCR assay

\begin{tabular}{|c|c|c|c|c|c|c|}
\hline \multirow[b]{2}{*}{ Genus } & \multirow[b]{2}{*}{ Species } & \multirow[b]{2}{*}{ Pathotype } & \multirow[b]{2}{*}{ Strain name/Serotype } & \multicolumn{3}{|c|}{ Target gene } \\
\hline & & & & $Z 3276$ & $s t \times 1$ & $s t \times 2$ \\
\hline Escherichia & coli & EHEC & EDL933/O157:H7 & + & + & + \\
\hline Escherichia & coli & ETEC & EC1775/O26:H1 1 & - & + & - \\
\hline Escherichia & coli & STEC & EC1803/O103:H11 & - & + & + \\
\hline Escherichia & coli & STEC & EC1807/O121:H19 & - & - & + \\
\hline Escherichia & coli & ETEC & EC1801 & - & + & - \\
\hline Escherichia & coli & EPEC & EC1501 & - & - & - \\
\hline Escherichia & coli & EIEC & EC1513 & - & - & - \\
\hline Escherichia & coli & EDC & DEC5A & - & - & - \\
\hline \multirow[t]{2}{*}{ Escherichia } & coli & & K12/MG1655 & - & - & - \\
\hline & & & & - & - & - \\
\hline Salmonella & enterica & & SL192/Typhi & - & - & - \\
\hline Salmonella & enterica & & SL317/Newport & - & - & - \\
\hline \multirow[t]{2}{*}{ Salmonella } & enterica & & SL535/Typhimurim & - & - & - \\
\hline & & & & - & - & - \\
\hline Shigella & sonnei & & SH20145 & - & - & - \\
\hline Shigella & dysenteriae & & SH20152 & - & - & - \\
\hline Shigella & flexneri & & SH20155 & - & - & - \\
\hline \multirow[t]{2}{*}{ Shigella } & boydii & & SH2O140 & - & - & - \\
\hline & & & & - & - & - \\
\hline Staphylococcus & aureus & & ATCC25923 & - & - & - \\
\hline Staphylococcus & epidermidis & & ATCC12228 & - & - & - \\
\hline \multirow[t]{2}{*}{ Staphylococcus } & pyogenes & & ATCC19615 & - & - & - \\
\hline & & & & - & - & - \\
\hline Vibrio & alginolytica & & ATCC17749 & - & - & - \\
\hline Vibrio & parahemolyticus & & ATCC17802 & - & - & - \\
\hline \multirow[t]{2}{*}{ Vibrio } & vulasfians & & ATCC27562 & - & - & - \\
\hline & & & & - & - & - \\
\hline Enterobacter & cloacae & & ATTCC23355 & - & - & - \\
\hline Enterobacter & cloacae & & ATCC13047 & - & - & - \\
\hline \multirow[t]{2}{*}{ Enterobacter } & cloacae & & ATCC13048 & - & - & - \\
\hline & & & & - & - & - \\
\hline \multirow[t]{2}{*}{ Citrobacter } & freundii & & ATCC8090 & - & - & - \\
\hline & & & & - & - & - \\
\hline \multirow[t]{2}{*}{ Klebsiella } & pneumoniae & & ATCC13883 & - & - & - \\
\hline & & & & - & - & - \\
\hline Pseudomonas & aeruginosa & & ATCC27853 & - & - & - \\
\hline
\end{tabular}

agar plates at $37{ }^{\circ} \mathrm{C}$ overnight. DNA preparation from bacterial cultures was made with a Puregene cell and tissue kit (Gentra, Minneapolis, MN) as described previously [23]. Briefly, cell pellets from $1 \mathrm{ml}$ of overnight culture were suspended in $3 \mathrm{ml}$ of cell lysis solution and heated to $80{ }^{\circ} \mathrm{C}$ for $5 \mathrm{~min}$, followed by addition of $15 \mu \mathrm{l}$ of RNase A and incubation at $37{ }^{\circ} \mathrm{C}$ for $60 \mathrm{~min}$. To remove protein and cell debris, the cell lysate was further mixed with $1 \mathrm{ml}$ of protein precipitation solution, vortexed and centrifuged at $3000 \times \mathrm{g}$. DNA in the supernatant was precipitated by the addition of 2-propanol, centrifuged as above, washed with $70 \%$ ethanol, and 
Table 3 Primers and probes used in the multiplex real-time PCR assay

\begin{tabular}{|c|c|c|c|c|}
\hline $\begin{array}{l}\text { Target } \\
\text { gene }\end{array}$ & Primer/Probe & Sequence $\left(5^{\prime}-3^{\prime}\right)$ & $\begin{array}{l}\text { Amplicon } \\
\text { length (bp) }\end{array}$ & Reference \\
\hline \multirow[t]{3}{*}{ Z3276 } & Z3276 forward & TATTCCGCGATGCTTGTTTT & 130 & Li and Chen. 2012 \\
\hline & Z3276 reverse & ATTATCTCACCAGCAAACTGGCGG & & \\
\hline & Z3276 probe & FAM-CCCGCAAATCTTTCCMGBNFQ & & \\
\hline \multirow[t]{3}{*}{$s t \times 1$} & stx1 forward & GGATTTCGTACAACACTGGATGAT & 67 & This study \\
\hline & stx1 reverse & ATCCACATCTTCAGCAGTCATTACA & & \\
\hline & stx1 probe & TAMRA-CAGTGGGCGTTCTTMGBNFQ & & \\
\hline \multirow[t]{3}{*}{$s t \times 2$} & stx2 forward & GGGCAGTTATTTTGCTGTGGAT & 59 & This study \\
\hline & st $\times 2$ reverse & GGTCAAAACGCGCCTGAT & & \\
\hline & stx2 probe & JOE-ACGAGGGCTTGATGTCMGBNFQ & & \\
\hline \multirow[t]{3}{*}{ IAC } & IAC forward & CAGGATTAGCAGAGCGAGGTATG & 65 & Fricker et al. 2007 \\
\hline & IAC reverse & CGTAGTTAGGCCACCACTTCAAG & & \\
\hline & IAC probe & CY5-AGGCGGTGCTACAGAG-MGBNFQ & & \\
\hline
\end{tabular}

dissolved in $500 \mu \mathrm{l}$ of rehydration solution. The concentration of DNA extraction was determined by measuring the optical density $\left(\mathrm{OD}_{260}\right)$ using a NanoDrop spectrophotometer (NanoDrop Technology, Wilmington, DE)

Primers and probes for the multiplex real-time PCR assay All the primers, probes, and sequence information are listed in Table 3. The primers and labeled TaqMan probes in this study were designed using Primer Express 3.0 software (Life Technology, Foster City, CA) and synthesized by Life Technology. The primers and probe for E. coli O157:H7 specific gene open reading frame (ORF) ORFZ3276 were described previously [23], the primers and probes for stx 1 , and stx 2 were designed in this study, and the primers and probe for internal amplification control (IAC) were selected based on the DNA sequence of plasmid pUC19 as previously reported [42]. The IAC was incorporated into the multiplex real-time PCR assay to ensure the amplification is free of inhibitory factors from examined food samples.

\section{Development of the multiplex real-time PCR assay}

The multiplex real-time PCR assay was developed using the Life Technology ABI 7500 System platform and the standard chemistry. The concentrations of primers and probes for each target gene were adjusted to achieve optimal amplification condition. The reaction mixture contains $12.5 \mu \mathrm{l}$ of $2 \times$ Universal Master Mix (Life Technology), $200 \mathrm{nM}$ forward and reverse primers, appropriate concentrations of four probes [(Z3276 (80 $\mathrm{nM})$, st $x 1$ (80 nM), st $x 2(20 \mathrm{nM})$, and IAC (40 nM)] and $2 \mu \mathrm{l}$ of template DNA. Water was added to make a final reaction volume of $25 \mu \mathrm{l}$. The amplification conditions for the multiplex assay were set as follows: activation of TaqMan at $95{ }^{\circ} \mathrm{C}$ for $10 \mathrm{~min}$, then 40 cycles of denaturation at $95{ }^{\circ} \mathrm{C}$ for $10 \mathrm{~s}$ and annealing/extension at $60{ }^{\circ} \mathrm{C}$ for $60 \mathrm{~s}$.

To compare the efficiency of the multiplex assay with simplex assay, each of the target genes Z3276, stx1, and stx 2 was amplified by three individual simplex assays. For the simplex assays, three individual reaction mixtures each contains $12.5 \mu \mathrm{l}$ of $2 \times$ Universal Master Mix (Life Technology), corresponding forward and reverse primers $(200 \mathrm{nM})$ and probe $(100 \mathrm{nM})$. An equal amount of template DNA $(2 \mu \mathrm{l})$ was used for the simplex assays, and water was added to make a final reaction volume of $25 \mu \mathrm{l}$. The amplification conditions for simplex assays were the same as the multiplex assay.

\section{Sensitivity test and the limit of detection (LOD) of the multiplex qPCR assay}

To determine the sensitivity of the multiplex real-time PCR, standard curves of Z3276, st x 1, and st $x 2$ in the multiplex real-time PCR were generated. A serial 10-fold dilution from $10 \mathrm{ng}$ to $10 \mathrm{fg} / \mu \mathrm{l}$ of genomic DNA of $E$. coli O157:H7 strain (EDL933) was prepared and $2.0 \mu \mathrm{l}$ of each dilution was used as template for PCR amplification. The real-time PCR assay was performed using the conditions described as above. The amplification efficiency of the assay was determined using the formula $\mathrm{E}$ $=\left(10^{-1 / \text { slope }}-1\right)^{*} 100[43,44]$.

\section{Inclusivity and exclusivity tests}

The inclusivity test for the multiplex real-time PCR was performed with the optimized concentrations for probes Z3276, stx 1 and stx2 on the genomic DNA of E. coli O157:H7 strains $(\mathrm{n}=135)$ and non-O157 STEC strains $(\mathrm{n}=21)$ (Table 1$)$. The exclusivity test was performed on various pathogenic strains including strains of EIEC, EPEC, Shigella, and Salmonella $(\mathrm{n}=27)$ (Table 2). DNA 
samples were diluted with nuclease-free water to concentration of $50 \mathrm{pg} / \mu \mathrm{l}$ and $2 \mu \mathrm{l}$ of DNA dilute was used for amplification of target genes. Furthermore, $2 \mu \mathrm{l}$ of nuclease free water was used to substitute DNA in no template control in the triplex real-time PCR.

\section{Application of the multiplex real-time PCR assay to detect E. coli 0157:H7 from spiked spinach and beef}

Fresh spinach and beef were purchased from a local retail source and used as food matrices to assess the multiplex real-time PCR assay. These samples were first confirmed to be free of E. coli $\mathrm{O} 157: \mathrm{H} 7$ and non-O157 STEC by standard FDA BAM method [45], and subsequently used for the spiking experiments. One for beef (set 1) spinach spiking (set 2). Each set contained six replicates (25 $\mathrm{g}$ of beef or spinach), and were inoculated with 80 and $800 \mathrm{CFU} / \mathrm{g}$ O157:H7 (EDL933) cells, respectively. Each sample was mixed with $225 \mathrm{ml}$ of LB medium and homogenized for 2 min using a stomacher (Seward, England). The samples were incubated at $37^{\circ} \mathrm{C}$ with shaking at $180 \mathrm{rpm}$ for $24 \mathrm{~h}$.

Two $\mathrm{ml}$ of the enriched culture was sampled at $0,4,8$, 12 and $24 \mathrm{~h}$. At these times, the samples were centrifuged at $600 \times \mathrm{g}$ for $1 \mathrm{~min}$ to remove fat tissues (for beef) or leaf (for spinach) from the samples. The supernatants were transferred to 2-ml microtubes and centrifuged again at $3000 \times \mathrm{g}$ for $5 \mathrm{~min}$ to collect bacterial cells. The cell pellets were used for DNA extraction with PreMan Ultra Sample Preparation Reagent (Life Technologies), following the instruction of the manufacturer. Two $\mu$ of the DNA

a

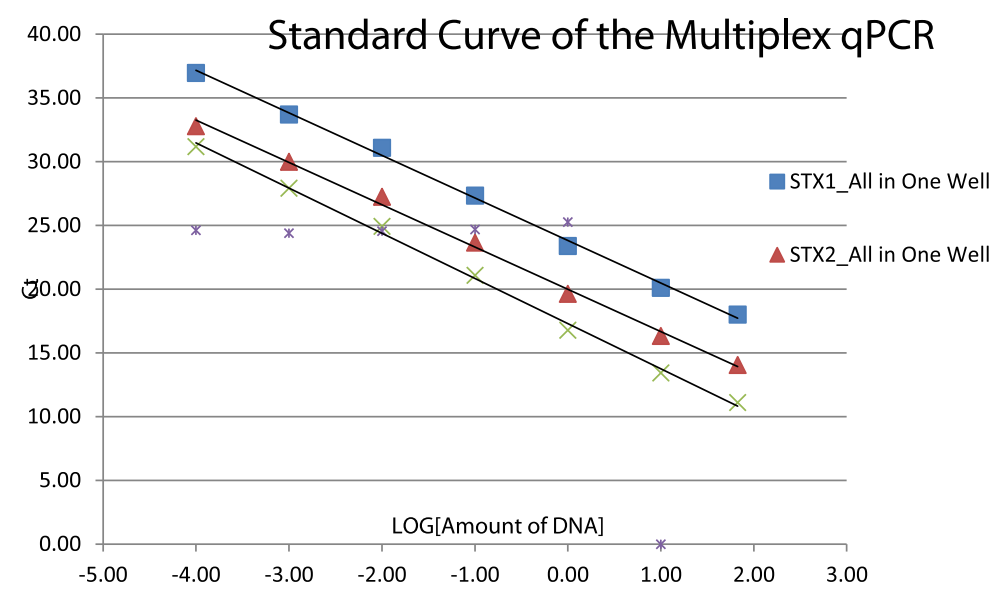

b

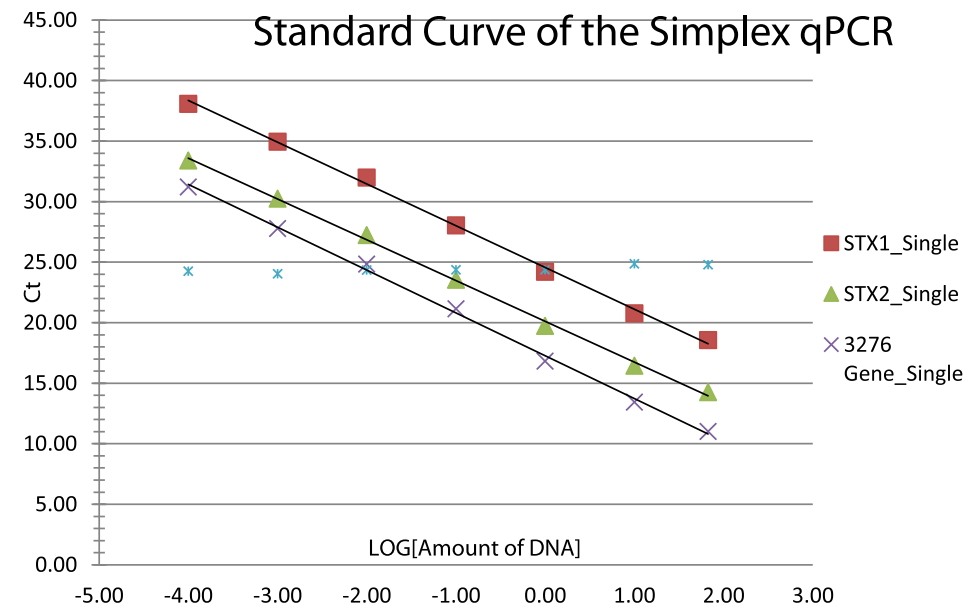

Fig. 1 Comparison of the sensitivity of simultaneously detecting the targeting genes Z3276, stx1, and stx2 in E. coli O157:H7 by the multiplex real-time PCR assay. The standard curves of Z3276, stx1, and stx2 created by the multiplex real-time PCR assay (a); the standard curves of 23276 , stx1, and stx2 generated by three individual simplex real-time PCR assays (b). The $C_{T}$ values represent the average of six replicates from two independent tests \pm SD 
extraction was used in the multiplex real-time PCR, and roughly 200 copies of plasmid pUC19 DNA (Promega, Madison, MI) was added as template for IAC.

\section{Results}

Designation and optimization of multiplex real-time PCR

Z3276 is a unique target gene that was used as the basis for a multiplex real-time PCR assay for the detection of E. coli $\mathrm{O} 157: \mathrm{H7}$. In addition to the Z3276 marker, three additional targets st $x 1, s t \times 2$, and IAC, were optimized for amplification and detection (data not shown). In order to minimize the interference among probes during the amplification process, the concentration of each probe was titrated and tested with a fixed amount of DNA (1 ng/reaction). The optimal concentrations for probes $Z 3276$, st $x 1$, st $x 2$, IAC were determined as 80 $\mathrm{nM}, 80 \mathrm{nM}, 20 \mathrm{nM}$, and $40 \mathrm{nM}$, respectively.

We further assessed whether the sensitivity of the probes was affected in the multiplex real-time PCR by comparing with those from the corresponding simplex assays. The $C_{T}$ values for the target genes Z3276, stx 1 , and stx 2 were determined to be 23.86, 22.23, and 21.22, respectively in the multiplex real-time PCR (Fig. 1a), whereas the $C_{T}$ values for Z3276, stx 1 , and stx 2 were $21.62,21.38$, and 20.63, respectively in simplex real-time PCR (Fig. 1b). These results demonstrated that at a specified amount of target DNA, the sensitivity of the multiplex PCR assay is comparable with that of each respective simplex assay.

\section{Comparison of sensitivity and specificity of the multiplex and simplex real-time PCR assays}

Using a serial 10-fold dilution of genomic DNA from $E$. coli O157:H7 (EDL933) as template, the limit of detection (LOD) in the multiplex real-time PCR was determined to be $200 \mathrm{fg}$ of DNA per reaction with average $C_{T}$ values of 38.63, 36.21, and 34.04 for Z3276, stx1, and stx2, respectively. The value of $200 \mathrm{fg}$ of DNA per reaction is equivalent to $40 \mathrm{CFU}$ of DNA. Three standard curves with slopes of $-3.60,-3.49$, and -3.36 , for the target genes Z3276, for stx1, and stx2, respectively, were generated and the amplification efficiencies for the three target genes differed slightly ranging from 90\% - 98\% (Fig. 1). These data indicated the sensitivity of the multiplex real-time PCR was robust and reliable.

\section{Inclusivity and exclusivity of the multiplex real-time PCR}

The multiplex real-time PCR positively identified all the E. coli $\mathrm{O} 157: \mathrm{H} 7$ strains $(\mathrm{n}=135)$ (Table 1$)$. This collection of 135 positively identified E. coli O157:H7 strains included the 21 strains that were not amplified in a realtime PCR assay targeting the uidA gene [23]. The Shiga toxin profiles (stx 1 and $s t \times 2)$ of these strains were also found to be perfectly matched with those previously determined by conventional PCR and uidA-based realtime PCR methods. No cross-reaction was observed from the E. coli $\mathrm{O} 157: \mathrm{H} 7$ specific probe $Z 3276$ on all the non-O157 STEC strains, Salmonella strains, Shigella strains, and other pathogenic strains; while the stx probes positively identified the non-O157 STEC strains with presence of either $s t x 1$ or $s t x 2$, or both (Table 1).

\section{Detection of E. coli 0157: $\mathrm{H7}$ from spiked food matrices by the multiplex real-time PCR assay}

Beef and spinach samples were initially inoculated with $80 \mathrm{CFU} / \mathrm{g}$ E. coli O157:H7 cells. At $0 \mathrm{~h}$, none of the three detection target genes (Z3276, st x 1 , and stx 2$)$ were detected by multiplex real-time PCR assay, but the IAC was positive. However, after 4 -h enrichment, all the three detection target genes (Z3276, st $x 1$, and stx2) from both food matrices were amplified in the multiplex realtime PCR assay (Table 4).

\section{Discussion}

PCR technology is widely used for pathogen detection from clinical, food, and environment samples. Real-time PCR methods are used for their enhanced sensitivity and specificity. Several PCR-based methods are available for the detection of $E$. coli $\mathrm{O} 157: \mathrm{H} 7$ and non-O157 STEC $(4,7,9,10)$ by amplifying various target genes [23]. Target genes such as stx [9, 12-20], eae [31, 32], fimA [33], $r f b E$ [34] have been used in various assays for detection of for $E$. coli $\mathrm{O} 157: \mathrm{H} 7$, however, most of those genes are not unique genetic markers for this pathogen [23]. This inadequate discriminatory power of those target genes calls for selection of more genetic markers for E. coli O157:H7. Consequently, we identified Z3276 as a unique genetic marker for detection of E. coli $\mathrm{O} 157: \mathrm{H} 7$ [23, 36], and confirmed by other scientific groups [37, 46].

Selection of $Z 3276$ as a unique genetic marker for detection of E. coli $\mathrm{O} 157: \mathrm{H} 7$ was the basis for the development of a multiplex PCR assay. Simultaneous detection of multiple genes in a single reaction may increase specificity and reliability for the detection of E. coli $\mathrm{O} 157: \mathrm{H} 7$, since the amplification of different target genes can corroborate the final conclusion. More importantly, the inclusion of the Shiga toxin genes enables the assay to detect not only E. coli O157:H7, but also screen for nonO157 STEC strains, the latter often underestimated [4753].

Multiplex real-time PCR can provide better detection efficiency. However, interference among probes and competition among primers for supplies during amplification may compromise the sensitivity and increase the background. Therefore, it is necessary to fine tune the parameters of the multiplex reaction to achieve the optimal conditions for each target gene. In this study, by optimizing the concentration of each probe in the assay 
Table 4 Detection results of the multiplex real-time PCR on the spiked food samples that inoculated with different concentations of E. coli O157:H7 and enriched with different incubation time

\begin{tabular}{|c|c|c|c|c|c|c|c|c|c|c|}
\hline \multirow[t]{3}{*}{ Target gene } & \multirow{3}{*}{$\begin{array}{l}\text { Food matrice } \\
\text { CFU/gram } \\
\text { Beef }\end{array}$} & \multicolumn{9}{|c|}{ Incubation time (h) } \\
\hline & & \multirow[t]{2}{*}{0} & \multicolumn{2}{|l|}{4} & \multicolumn{2}{|l|}{8} & \multicolumn{2}{|l|}{12} & \multicolumn{2}{|l|}{24} \\
\hline & & & $C_{T}^{a}$ & $\pm \mathrm{SD}$ & $C_{T}$ & $\pm \mathrm{SD}$ & $C_{T}$ & $\pm \mathrm{SD}$ & $C_{T}$ & $\pm \mathrm{SD}$ \\
\hline \multirow[t]{2}{*}{ Z3276 } & 80 & $U D^{b}$ & 34.50 & 0.29 & 28.43 & 0.07 & 27.98 & 0.10 & 27.98 & 0.10 \\
\hline & 800 & UD & 30.51 & 0.38 & 24.54 & 0.10 & 24.00 & 0.04 & 24.00 & 0.04 \\
\hline \multirow[t]{2}{*}{$s t \times 1$} & 80 & UD & 27.54 & 0.19 & 21.73 & 0.22 & 20.84 & 0.25 & 19.06 & 0.36 \\
\hline & 800 & UD & 24.45 & 0.22 & 18.51 & 0.14 & 17.46 & 0.03 & 18.48 & 0.02 \\
\hline \multirow[t]{2}{*}{$s t \times 2$} & 80 & UD & 31.34 & 0.10 & 25.47 & 0.02 & 25.03 & 0.04 & 23.63 & 0.02 \\
\hline & 800 & UD & 27.93 & 0.34 & 21.68 & 0.03 & 21.33 & 0.06 & 22.52 & 0.05 \\
\hline \multirow[t]{2}{*}{ IAC } & 200 copies $^{c}$ & 28.88 & 27.72 & & 21.96 & & 21.09 & & 19.59 & \\
\hline & Spinach & & $C_{T}$ & $\pm \mathrm{SD}$ & $C_{T}$ & $\pm \mathrm{SD}$ & $C_{T}$ & $\pm \mathrm{SD}$ & $C_{T}$ & $\pm \mathrm{SD}$ \\
\hline \multirow[t]{2}{*}{ Z3276 } & 80 & UD & 33.92 & 0.04 & 24.32 & 0.26 & 22.86 & 0.15 & 24.26 & 0.09 \\
\hline & 800 & UD & 30.91 & 0.05 & 23.04 & 0.11 & 23.08 & 0.08 & 23.12 & 0.07 \\
\hline \multirow[t]{2}{*}{$s t \times 1$} & 80 & UD & 27.63 & 0.16 & 17.32 & 0.15 & 15.74 & 0.13 & 16.87 & 0.11 \\
\hline & 800 & UD & 25.04 & 0.06 & 16.57 & 0.12 & 16.25 & 0.15 & 16.37 & 0.10 \\
\hline \multirow[t]{2}{*}{$s t \times 2$} & 80 & UD & 30.88 & 0.06 & 21.21 & 0.07 & 20.10 & 0.06 & 21.64 & 0.07 \\
\hline & 800 & UD & 28.19 & 0.14 & 20.05 & 0.15 & 20.58 & 0.05 & 20.74 & 0.04 \\
\hline IAC & 200 copies & 24.94 & 23.82 & & 24.77 & & 23.83 & & 23.69 & \\
\hline
\end{tabular}

Data were shown as average of two independent experiment

bUD refers to "Underdetermined", a negative detection result

${ }^{c}$ About 200 copies of pUC19 plasmid DNA was added as template for IAC to each multiplex real-time PCR reaction

(Z3276, stx1, and stx2), we were able to achieve robust sensitivity in the multiplex assay, and positively identified all the E. coli O157:H7 strains (n = 135), demonstrating the multiplex assay is compatible to the simplex assays.

Nowadays, WGS has been explored for a more efficient and more comprehensive approach for STEC detection. Although WGS potential with STEC characterization and surveillance is apparent, STEC detection will likely continue to rely on a combination of culture and non-culture methods, the latter including real-time PCR [49]. The multiplex real-time PCR developed in this study not only can detect $E$. coli $\mathrm{O} 157: \mathrm{H} 7$ and its profile of the Shiga toxin genes, but also detect non-O157 STEC strains. The capability for simultaneous detection of the Shiga toxin genes and the differentiation of E. coli O157:H7 from non-O157 STEC strains offers several advantages: i) determination of the presence or absence of Shiga toxin genes can be used to verify the detection results of $E$. coli $\mathrm{O} 157: \mathrm{H} 7$, because almost all E. coli $\mathrm{O} 157: \mathrm{H} 7$ strains possess $s t x 1$ and/or stx 2 gene(s); ii) profile of the Shiga toxin genes of E. coli O157:H7 provides genetic markers for differentiating isolates from outbreaks; iii) differentiation of $s t x 1$ and $s t x 2$ harboring E. coli $\mathrm{O} 157: \mathrm{H} 7$ strains may help health care providers manage HUS patients caused by E. coli O157:H7 [49]; and iv) identification of $s t x$ gene harboring isolates can serve as a useful clue for detection of STEC, and then more comprehensive and sophistical analytical analyses, such as cultural biological tests, toxin detection, serotyping, genotyping, and WGS, can be performed to confirm the final detection result.

Multiplex real-time PCR targeting uidA, stx 1 , and st $x 2$ genes for detection of E. coli $\mathrm{O} 157: \mathrm{H} 7$ and non-O157 STECs has become a routine test for preliminary screening in clinical laboratories as the Centers for Disease Control and Prevention recommended [54]. Although WGS is not yet a routine testing, future prediction would include this technology as a means to track the mobility of pathogenic microbes as the food market has become global. The multiplex real-time PCR developed in this study has been demonstrated to be a reliable, efficient, and sensitive assay, and may serve as a useful method for the detection of E. coli O157:H7 and nonO157 STEC in epidemiological surveillance programs as well as in food analytical laboratories. The multiplex real-time PCR assay was successfully tested in this study for the detection of E. coli O157:H7 from spiked food matrices, i.e., beef and spinach, and more than likely applicable to other food matrices.

It is worth noting that on the one hand, in the development of the multiplex real-time PCR assay, great efforts were made toward getting high sensitivity and specificity by optimizing the amplification conditions and by minimizing the interferences among probes, primers, and target genes to reduce the false negative 
rate in detection; on the other hand, in the use of the assay, precaution is needed in interpretation of the positive results from certain strains that free phages might harbor stx gene [55-57] or even some Shigella strains acquired stx genes [58-61].

\section{Conclusions}

A multiplex real-time PCR assay that can rapidly and simultaneously detect $E$. coli $\mathrm{O} 157: \mathrm{H} 7$ and screen for non-O157 STEC strains has been developed and assessed for efficacy. The inclusivity and exclusivity tests demonstrated high sensitivity and specificity of the multiplex real-time PCR assay. In addition, this multiplex assay was shown to be effective for the detection of E. coli $\mathrm{O} 157: \mathrm{H} 7$ from two common food matrices, beef and spinach, and may be applied for detection of $E$. coli O157:H7 and screening for non-O157 STEC strains from other food matrices as well.

\section{Abbreviations}

HUS: hemolytic-uremic syndrome; IAC: internal amplification control; ORF: open reading frame; STEC: Shiga toxin-producing Escherichia coli

\section{Acknowledgments}

WW was supported by a fellowship appointment administered by Oak Ridge Institute for Science and Education.

\section{Funding}

This research project including the design of the study, collection, analysis, and interpretation of data, and writing the manuscript was all funded by the U.S. Food and Drug Administration.

\section{Availability of data and materials}

The datasets used and/or analyzed during the current study are available from the corresponding author on reasonable request.

\section{Authors' contributions}

$B L$ conceived the project. $B L$ and $H L$ designed the study. $B L, H L$, and $W W$ performed the experiments and analyzed the results. BL and $\mathrm{HL}$ wrote the manuscript. All authors read and approved the final manuscript.

\section{Ethics approval and consent for participation}

Not applicable.

\section{Consent for publication}

Not applicable.

\section{Competing interests}

The authors declare that they have no competing interests.

\section{Author details}

'Division of Molecular Biology, Center for Food Safety and Applied Nutrition, Food and Drug Administration, Laurel, MD 20708, USA. ${ }^{2}$ Branch of Microbiology, Office of Regulatory Affairs, Food and Drug Administration, Jefferson, AR 72079, USA.

Received: 26 June 2017 Accepted: 27 October 2017

Published online: 09 November 2017

\section{References}

1. Parsons BD, Zelyas N, Berenger BM, Chui L. Detection, Characterization, and Typing of Shiga Toxin-Producing Escherichia coli. Frontiers in Microbiology. 2016;7(478)

2. Scallan E, Griffin PM, Angulo FJ, Tauxe RV, Hoekstra RM. Foodborne illness acquired in the United States-unspecified agents. Emerg Infect Dis. 2011; 17(1):16-22
3. Schimmer B, Nygard K, Eriksen HM, Lassen J, Lindstedt BA, Brandal LT, Kapperud G, Aavitsland P. Outbreak of haemolytic uraemic syndrome in Norway caused by stx2-positive Escherichia coli 0103:H25 traced to cured mutton sausages. BMC Infect Dis. 2008;8:41.

4. Lee JE, Reed J, Shields MS, Spiegel KM, Farrell LD, Sheridan PP. Phylogenetic analysis of Shiga toxin 1 and Shiga toxin 2 genes associated with disease outbreaks. BMC Microbiol. 2007;7:109

5. Paton JC, Paton AW. Pathogenesis and diagnosis of Shiga toxin-producing Escherichia coli infections. Clin Microbiol Rev. 1998;11(3):450-79.

6. Riley LW, Remis RS, Helgerson SD, McGee HB, Wells JG, Davis BR, Hebert RJ, Olcott ES, Johnson LM, Hargrett NT, et al. Hemorrhagic colitis associated with a rare Escherichia coli serotype. N Engl J Med. 1983;308(12):681-5

7. Mead PS, Slutsker L, Dietz V, McCaig LF, Bresee JS, Shapiro C, Griffin PM, Tauxe RV. Food-related illness and death in the United States. Emerg Infect Dis. 1999;5(5):607-25.

8. Heiman KE, Mody RK, Johnson SD, Griffin PM, Gould LH. Escherichia coli 0157 Outbreaks in the United States, 2003-2012. Emerg Infect Dis. 2015; 21(8):1293-301.

9. Deisingh AK, Thompson M. Strategies for the detection of Escherichia coli 0157:H7 in foods. J Appl Microbiol. 2004:96(3):419-29.

10. DeGrandis S, Law H, Brunton J, Gyles C, Lingwood CA. Globotetraosylceramide is recognized by the pig edema disease toxin. J Biol Chem. 1989;264(21):12520-5.

11. Jinneman KC, Yoshitomi K, Weagant SD. Multiplex real-time PCR method to identify Shiga toxin genes stx 1 and stx2 and Escherichia coli O157:H7/Hserotype. Appl Environ Microbiol. 2003;69(10):6327-33.

12. Gannon VP, King RK, Kim JY, Thomas EJ. Rapid and sensitive method for detection of Shiga-like toxin-producing Escherichia coli in ground beef using the polymerase chain reaction. Appl Environ Microbiol. 1992;58(12):3809-15.

13. Lefterova MI, Slater KA, Budvytiene I, Dadone PA, Banaei N. A sensitive multiplex, real-time PCR assay for prospective detection of Shiga toxinproducing Escherichia coli from stool samples reveals similar incidences but variable severities of non-0157 and 0157 infections in northern California. J Clin Microbiol. 2013;51(9):3000-5.

14. Hara-Kudo Y, Konishi N, Ohtsuka K, Iwabuchi K, Kikuchi R, Isobe J, Yamazaki T, Suzuki F, Nagai Y, Yamada H, et al. An interlaboratory study on efficient detection of Shiga toxin-producing Escherichia coli O26, 0103, 0111, 0121, 0145, and 0157 in food using real-time PCR assay and chromogenic agar. International Journal of Food Microbiology. 2016;230:81-8.

15. Verhaegen B, Van Damme I, Heyndrickx M, Botteldoorn N, Elhadidy M, Verstraete K, Dierick K, Denayer S, De Zutter L, De Reu K. Evaluation of detection methods for non-0157 Shiga toxin-producing Escherichia coli from food. International Journal of Food Microbiology. 2016;219:64-70.

16. Brusa V, Galli L, Linares LH, Ortega EE, Lirón JP, Leotta GA. Development and validation of two SYBR green PCR assays and a multiplex real-time PCR for the detection of Shiga toxin-producing Escherichia coli in meat. Journal of Microbiological Methods. 2015;119:10-7.

17. Harada T, Iguchi A, lyoda S, Seto K, Taguchi M, Kumeda Y. Multiplex Real-Time PCR Assays for Screening of Shiga Toxin 1 and 2 Genes, Including All Known Subtypes, and Escherichia coli O26-, O111-, and O157-Specific Genes in Beef and Sprout Enrichment Cultures. J Food Prot. 2015:78(10):1800-11.

18. Tunsjø HS, Kvissel AK, Follin-Arbelet B, Brotnov BM, Ranheim TE, Leegaard TM. Suitability of stx-PCR directly from fecal samples in clinical diagnostics of STEC. APMIS. 2015;123(10):872-8.

19. de Boer RF, Ferdous M, Ott A, Scheper HR, Wisselink GJ, Heck ME, Rossen JW, Kooistra-Smid AM. Assessing the public health risk of Shiga toxinproducing Escherichia coli by use of a rapid diagnostic screening algorithm. J Clin Microbiol. 2015:53(5):1588-98.

20. Baliere C, Rince A, Thevenot D, Gourmelon M. Successful detection of pathogenic Shiga-toxin-producing Escherichia coli in shellfish, environmental waters and sediment using the ISO/TS-13136 method. Lett Appl Microbiol. 2015:60(4):315-20.

21. Frank C, Werber D, Cramer JP, Askar M, Faber M, an der Heiden M, Bernard H, Fruth A, Prager R, Spode A et al: Epidemic Profile of Shiga-ToxinProducing Escherichia coli 0104:H4 Outbreak in Germany. New England Journal of Medicine 2011, 365(19):1771-1780.

22. March SB, Ratnam S. Sorbitol-MacConkey medium for detection of Escherichia coli 0157:H7 associated with hemorrhagic colitis. J Clin Microbiol. 1986;23(5):869-72 
23. Li B, Chen JQ. Real-time PCR methodology for selective detection of viable Escherichia coli 0157:H7 cells by targeting Z3276 as a genetic marker. Appl Environ Microbiol. 2012;78(15):5297-304.

24. Cebula TA, Payne WL, Feng P. Simultaneous identification of strains of Escherichia coli serotype 0157:H7 and their Shiga-like toxin type by mismatch amplification mutation assay-multiplex PCR. J Clin Microbiol. 1995;33(1):248-50

25. Fratamico PM, DebRoy C, Liu Y, Needleman DS, Baranzoni GM, Feng P. Advances in Molecular Serotyping and Subtyping of Escherichia colit. Frontiers in Microbiology. 2016;7(644)

26. Jackson SA, Kotewicz ML, Patel IR, Lacher DW, Gangiredla J, Elkins CA. Rapid genomic-scale analysis of Escherichia coli 0104:H4 by using high-resolution alternative methods to next-generation sequencing. Appl Environ Microbiol. 2012;78(5):1601-5.

27. Patel IR, Gangiredla J, Lacher DW, Mammel MK, Jackson SA, Lampel KA, Elkins CA. FDA Escherichia coli Identification (FDA-ECID) Microarray: a Pangenome Molecular Toolbox for Serotyping, Virulence Profiling, Molecular Epidemiology, and Phylogeny. Appl Environ Microbiol. 2016;82(11):3384-94.

28. Lindsey RL, Pouseele H, Chen JC, Strockbine NA, Carleton HA. Implementation of Whole Genome Sequencing (WGS) for Identification and Characterization of Shiga Toxin-Producing Escherichia coli (STEC) in the United States. Frontiers in Microbiology. 2016;7(766)

29. Leonard SR, Mammel MK, Lacher DW, Elkins CA. Strain-Level Discrimination of Shiga Toxin-Producing Escherichia coli in Spinach Using Metagenomic Sequencing. PLoS One. 2016;11(12):e0167870.

30. Elizaquivel P, Aznar R. A multiplex RTi-PCR reaction for simultaneous detection of Escherichia coli 0157:H7, Salmonella spp. and Staphylococcus aureus on fresh, minimally processed vegetables. Food Microbiol. 2008;25(5):705-13.

31. Barletta F, Ochoa TJ, Ecker L, Gil Al, Lanata CF, Cleary TG. Validation of fivecolony pool analysis using multiplex real-time PCR for detection of diarrheagenic Escherichia coli. J Clin Microbiol. 2009;47(6):1915-7.

32. Schmidt H, Plaschke B, Franke S, Russmann H, Schwarzkopf A, Heesemann J, Karch $\mathrm{H}$. Differentiation in virulence patterns of Escherichia coli possessing eae genes. Med Microbiol Immunol. 1994;183(1):23-31.

33. Li B, Koch WH, Cebula TA. Detection and characterization of the fimA gene of Escherichia coli O157:H7. Mol Cell Probes. 1997;11(6):397-406.

34. Desmarchelier PM, Bilge SS, Fegan N, Mills L, Vary JC, Jr., Tarr PI: A PCR specific for Escherichia coli $\mathrm{O} 157$ based on the rfb locus encoding 0157 lipopolysaccharide. J Clin Microbiol 1998, 36(6):1801-1804.

35. Fields PI, Blom K, Hughes HJ, Helsel LO, Feng P, Swaminathan B. Molecular characterization of the gene encoding $\mathrm{H}$ antigen in Escherichia coli and development of a PCR-restriction fragment length polymorphism test for identification of E. coli O157:H7 and 0157:NM. J Clin Microbiol. 1997;35(5): 1066-70.

36. Li B, Hu Z, Elkins CA. Detection of live Escherichia coli O157:H7 cells by PMA-qPCR. J Vis Exp. 2014;84:e50967.

37. Ravan H, Amandadi M, Sanadgol N. A highly specific and sensitive loopmediated isothermal amplification method for the detection of Escherichia coli O157:H7. Microb Pathog. 2016;91:161-5.

38. Feng $P$, Lampel KA. Genetic analysis of uidA expression in enterohaemorrhagic Escherichia coli serotype 0157:H7. Microbiology. 1994; 140(Pt 8):2101-7.

39. Monday SR, Whittam TS, Feng PC. Genetic and evolutionary analysis of mutations in the gusA gene that cause the absence of beta-glucuronidase activity in Escherichia coli 0157:H7. J Infect Dis. 2001;184(7):918-21.

40. Perna NT, Plunkett G, 3rd, Burland V, Mau B, Glasner JD, Rose DJ, Mayhew GF, Evans PS, Gregor J, Kirkpatrick HA et al: Genome sequence of enterohaemorrhagic Escherichia coli O157:H7. Nature 2001, 409(6819): 529-533.

41. Fratamico PM, Wasilenko JL, Garman B, Demarco DR, Varkey S, Jensen M, Rhoden K, Tice G. Evaluation of a multiplex real-time PCR method for detecting shiga toxin-producing Escherichia coli in beef and comparison to the U.S. Department of Agriculture Food Safety and Inspection Service Microbiology laboratory guidebook method. J Food Prot. 2014;77(2):180-8.

42. Fricker $M$, Messelhausser $U$, Busch $U$, Scherer S, Ehling-Schulz M. Diagnostic real-time PCR assays for the detection of emetic Bacillus cereus strains in foods and recent food-borne outbreaks. Appl Environ Microbiol. 2007;73(6): 1892-8.

43. Pfaffl MW. A new mathematical model for relative quantification in real-time RT-PCR. Nucleic Acids Res. 2001;29(9):e45.
44. Pfaffl MW, Horgan GW, Dempfle L. Relative expression software tool (REST) for group-wise comparison and statistical analysis of relative expression results in real-time PCR. Nucleic Acids Res. 2002;30(9):e36.

45. Administration FD. Diarrheagenic Escherichia coli. Bacteriological Analytical Manual. Gaithersburg, MD USA; 2011.

46. Ravan H, Amandadi M. Analysis of yeh Fimbrial Gene Cluster in Escherichia coli 0157:H7 in Order to Find a Genetic Marker for this Serotype. Curr Microbiol. 2015;71(2):274-82.

47. Chui L, Lee M-C, Allen R, Bryks A, Haines L, Boras V. Comparison between ImmunoCard STAT! $!^{\oplus}$ and real-time PCR as screening tools for both 0157:H7 and non-O157 Shiga toxin-producing Escherichia coli in Southern Alberta, Canada. Diagnostic Microbiology and Infectious Disease. 2013;77(1):8-13.

48. Gould LH, Walsh KA, Vieira AR, Herman K, Williams IT, Hall AJ, Cole D, Centers for Disease C, Prevention: Surveillance for foodborne disease outbreaks - United States, 1998-2008. MMWR Surveill Summ 2013, 62(2):1-34.

49. Parsons BD, Zelyas N, Berenger BM, Chui L. Detection, Characterization, and Typing of Shiga Toxin-Producing Escherichia coli. Front Microbiol. 2016;7:478

50. Fratamico PM, Briggs CE, Needle D, Chen CY, DebRoy C. Sequence of the Escherichia coli $0121 \mathrm{O}$-antigen gene cluster and detection of enterohemorrhagic E. coli 0121 by PCR amplification of the wzx and wzy genes. J Clin Microbiol. 2003;41(7):3379-83.

51. Wickham ME, Lupp C, Mascarenhas M, Vazquez A, Coombes BK, Brown NF, Coburn BA, Deng W, Puente JL, Karmali MA, et al. Bacterial genetic determinants of non-0157 STEC outbreaks and hemolytic-uremic syndrome after infection. J Infect Dis. 2006;194(6):819-27.

52. Kuehne A, Bouwknegt M, Havelaar A, Gilsdorf A, Hoyer P, Stark K, Werber D, and the HUSasnG: Estimating true incidence of 0157 and non-0157 Shiga toxin-producing Escherichia coli illness in Germany based on notification data of haemolytic uraemic syndrome. Epidemiol Infect 2016, 144(15):33053315.

53. Mora A, Blanco M, Blanco JE, Dahbi G, Lopez C, Justel P, Alonso MP, Echeita A, Bernardez MI, Gonzalez EA, et al. Serotypes, virulence genes and intimin types of Shiga toxin (verocytotoxin)-producing Escherichia coli isolates from minced beef in Lugo (Spain) from 1995 through 2003. BMC Microbiol. 2007; 7:13.

54. Gould MS, Marrocco FA, Hoagwood K, Kleinman M, Amakawa L, Altschuler E. Service use by at-risk youths after school-based suicide screening. J Am Acad Child Adolesc Psychiatry. 2009;48(12):1193-201.

55. Monday SR, Beisaw A, Feng PC. Identification of Shiga toxigenic Escherichia coli seropathotypes A and B by multiplex PCR. Mol Cell Probes. 2007;21(4): 308-11.

56. Martinez-Castillo A, Muniesa M. Implications of free Shiga toxin-converting bacteriophages occurring outside bacteria for the evolution and the detection of Shiga toxin-producing Escherichia coli. Front Cell Infect Microbiol. 2014:4:46

57. Grys TE, Sloan LM, Rosenblatt JE, Patel R. Rapid and sensitive detection of Shiga toxin-producing Escherichia coli from nonenriched stool specimens by real-time PCR in comparison to enzyme immunoassay and culture. J Clin Microbiol. 2009;47(7):2008-12.

58. Strauch E, Lurz R, Beutin L. Characterization of a Shiga toxin-encoding temperate bacteriophage of Shigella sonnei. Infect Immun. 2001;69(12): 7588-95.

59. Gray MD, Lampel KA, Strockbine NA, Fernandez RE, Melton-Celsa AR, Maurelli AT. Clinical isolates of Shiga toxin 1a-producing Shigella flexneri with an epidemiological link to recent travel to Hispaniola. Emerg Infect Dis. 2014;20(10):1669-77.

60. Carter CC, Fierer J, Chiu WW, Looney DJ, Strain M, Mehta SR: A Novel Shiga Toxin 1a-Converting Bacteriophage of Shigella sonnei With Close Relationship to Shiga Toxin 2-Converting Pages of Escherichia coli. Open Forum Infect Dis 2016, 3(2):ofw079.

61. Kozyreva VK, Jospin G, Greninger AL, Watt JP, Eisen JA, Chaturvedi V. Recent Outbreaks of Shigellosis in California Caused by Two Distinct Populations of Shigella sonnei with either Increased Virulence or Fluoroquinolone Resistance. mSphere. 2016;1(6) 